\title{
SURGICAL VS. CONSERVATIVE TREATMENT FOR DEGENERATIVE LUMBAR STENOSIS
}

\author{
TRATAMENTO CIRÚRGICO VS. CONSERVADOR DE ESTENOSE LOMBAR DEGENERATIVA
}

TRATAMIENTO QUIRÚRGICO VS. CONSERVADOR PARA LA ESTENOSIS LUMBAR DEGENERATIVA

Caio Roncon Dias ${ }^{1}$, Nelson Astur ${ }^{1}$, Ricardo Shigueaki Galhego Umeta', Maria Fernanda Silber Caffaro¹, Osmar Avanzi ${ }^{1}$, Robert Meves ${ }^{1}$

\begin{abstract}
Objectives: To compare the clinical outcomes between patients with degenerative lumbar stenosis who were treated by decompression with those awaiting the same kind of treatment for the disease. Methods: Retrospective study which divided patients with degenerative lumbar stenosis with surgical indication in 2 groups, operated and awaiting the procedure. The Oswestry Disability Index (ODI) questionnaire, visual analog scale and SF36 were applied. Results: Twelve operated patients and 18 awaiting the procedure were included. The average age of those operated was 59 years (43-70), and $55(37-82)(p=0.3)$ for those awaiting surgery. The operated group had a mean ODI of 38.67 against $59.72(p<0.05)$ in the non-operated group. The pain analog scale had lumbar result of 5.33 and pain radiating to the lower limbs of 3.83 in operated patients, against $6.78(p>0.05)$ and $7.22(p<0.05)$ in the awaiting surgery patients, respectively. As for the SF36 scale, functional capacity, limitations due to physical aspects and pain had an average score of 36.25, 19.58 and 21.67 in the operated group against $35.94,27.50$ and 32.61 in the awaiting group ( $p>0.05)$, respectively. Conclusion: The operated patients showed improvement of referred pain in the lower limbs (leg VAS) and improved function (Oswestry), however showed no significant change in quality of life according to SF36 scale and low back pain (lumbar VAS) were found.
\end{abstract}

Keywords: Spinal Stenosis; Lumbar vertebrae; Low back pain; Therapeutics; Quality of life.

\section{RESUMO}

Objetivos: Comparar os resultados clínicos entre os pacientes com estenose lombar degenerativa que foram tratados por descompressão com aqueles que aguardam o mesmo tipo de tratamento para a doença. Métodos: Estudo retrospectivo que dividiu os pacientes com estenose lombar degenerativa com indicação cirúrgica em dois grupos, operados e que aguardam o procedimento. Foram aplicados o questionário Oswestry Disability Index (ODI), Escala Visual Analógica e SF36. Resultados: Foram incluídos 12 pacientes operados e 18 pacientes que aguardam o procedimento. A média de idade dos operados foi 59 anos (43-70) e a dos que aguardam a cirurgia foi 55 (37-82) ( $p=0,3)$. O grupo operado teve ODI médio de 38,67 contra 59,72 dos que aguardavam ( $p<0,05)$. A escala analógica da dor teve resultado lombar de 5,33 e de dor irradiada para os membros inferiores de 3,83 nos operados, contra 6,78 (p > 0,05) e $7,22(p<0,05)$, respectivamente, no grupo que aguarda cirurgia. Quanto à escala SF36, capacidade funcional, limitação por aspectos físicos e dor tiveram resultado médio de 36,25, 19,58 e 21,67 nos pacientes operados contra 35,94, 27,50 e 32,61, respectivamente, nos ainda não operados ( $p>0,05)$. Conclusão: Os pacientes operados apresentaram melhora da dor reflexa nos membros inferiores (VAS Perna) e melhora na função (Oswestry), porém não demonstraram alteração significativa da qualidade de vida segundo a escala SF36 e dor lombar (VAS Lombar).

Descritores: Estenose espinal; Vértebras lombares; Dor lombar; Terapêutica; Qualidade de vida.

\section{RESUMEN}

Objetivos: Comparar los resultados clínicos entre los pacientes con estenosis lumbar degenerativa tratados mediante descompresión y los que esperan el procedimiento para la enfermedad. Métodos: Estudio retrospectivo que dividió a los pacientes con estenosis degenerativa lumbar con indicación quirúrgica en dos grupos, operado y en espera del procedimiento. Se aplicaron el cuestionario de Oswestry Disability Index (ODI), el SF36 y la escala visual analógica (EVA). Resultados: Se incluyeron 12 pacientes que recibieron tratamiento quirúrgico y 18 pacientes en espera de la cirugía. La edad media de los operados fue de 59 años (43-70), y de los que esperaban el procedimiento fue de 55 (37-82) ( $p=0,3)$. El grupo operado tuvo ODI promedio de 38.67 contra 59.72 del grupo de espera $(p<0,05)$. La escala analógica del dolor lumbar tuvo resultado de 5,33 y el dolor que se irradia a las extremidades inferiores de 3,83 en los operados contra 6,78 ( $p>0,05)$ y $7,22$ ( $p<0,05)$, respectivamente, en el grupo de espera de la cirugía. En cuanto a la escala SF-36, la capacidad funcional, las limitaciones debidas a aspectos físico y el dolor tuvieron puntuación media de 36,25, 19,58 y 21,67 en pacientes operados contra 35,94, 27,50 y 32,61, respectivamente, en los que esperan la cirugía $(p>0,05)$. Conclusión: Los pacientes operados mostraron una mejoría del dolor referido en las extremidades inferiores (EVA de la pierna) y mejoría de la función (Oswestry). Sin embargo, no se observaron cambios significativos con respecto al dolor lumbar (EVA lumbar) ni en la calidad de vida medida a través del cuestionario SF-36.

Descriptores: Estenosis espinal; Vértebras lumbares; Dolor de la región lumbar; Terapéutica; Calidad de vida.

1. School of Medical Sciences of the Santa Casa de São Paulo - "Fernandinho Simonsen" Pavillion, Departament of Orthopedics andTraumatology, São Paulo, SP, Brazil.

Study conducted at the School of Medical Sciences of the Santa Casa de São Paulo - "Fernandinho Simonsen" Pavillion, Departament of Orthopedics andTraumatology, São Paulo, SP, Brazil. Correspondence: Rua Dr. Cesário Motta Jr, 112. São Paulo, SP, Brazil. 01227-900. dot.coluna@ santacasasp.org.br 


\section{INTRODUCTION}

Lumbar stenosis is characterized by a reduction in the space available for the neural elements of the vertebral canal of the lumbar spine, frequently leading to clinical symptoms. When it is degenerative in nature, it results in a series of progressive changes in the structures that comprise and surround the spinal canal. In general, there is degenerative hypertrophy of the ligaments and capsules, osteophytosis, and progressive deterioration of the intervertebral discs, with the consequent instability or hypermobility of the facet joints, also leading to hypertrophy. When it is symptomatic, the narrowing of the channel available for the cauda equina in the lumbar spine manifests with pain radiating to the lower limbs, and often with neurogenic claudication, in addition to mechanical lower back pain. The diagnosis is made through a combination of the clinical profile and imaging exams, such as radiography and magnetic resonance. ${ }^{1}$

In the absence of neurological deficit, the initial treatment of lumbar stenosis is conservative, with good outcomes in $15 \%$ to $50 \%$ of patients, without the need for surgery. ${ }^{2}$ This is reserved for cases of neurogenic claudication or incapacitating pain, where there is no improvement after conservative treatment. Surgery has better outcomes in patients with stenosis in a single level, weakness lasting less than six months, under 64 years of age, and with monoradiculopathy. Weinstein et al. ${ }^{3}$ indicate surgery for patients who have had neurogenic claudication or radicular symptoms for more than 12 months associated with stenosis of the canal observed in an axial magnetic resonance slice. The surgical indication for lumbar stenosis is still controversial, and the criteria are not always clear. More recent studies $^{4-8}$ question the real efficacy of the procedure, and whether the results significantly improve the quality of life of the patients. It is difficult to compare the improvement of patients objectively following surgery, given that even after considerable decompressions, some patients continue to present symptoms.

The objective of this study is to compare the efficacy of the surgical treatment for lumbar stenosis in patients who have already undergone surgery with the patients who have a surgical indication but are still waiting to undergo the procedure.

\section{MATERIALS AND METHODS}

Following approval by the Institutional Review Board, a retrospective search was carried out, of the medical records of patients in medical follow-up at the Spine Group of the Department of Orthopedics and Traumatology who received surgical treatment for lumbar stenosis in the form of posterior approach decompression and instrumented arthrodesis, and of those with the same diagnosis confirmed by magnetic resonance, with symptoms lasting more than 12 months, and an indication of surgery, but who still were waiting for the surgery to be scheduled. The inclusion criteria used were: a complete set of medical records including imaging exams, a minimum follow-up period of 3 months, and the absence of neoplasia, osteoporosis, or associated vertebral fracture. Patients not wishing to participate in the study, patients with a diagnosis other than vertebral stenosis of the lumbar spine or associated spondylolisthesis, patients without a confirmed diagnosis (incomplete records or lost imaging exams), or patients with prior spine surgery for another reason, were excluded. After selecting potential participants, they were asked to appear for a clinical and functional evaluation. A total of 30 patients were identified during the period from April 2013 to December 2013, all of whom wished to participate in the study and signed an Informed Consent Form.

The selected patients were allocated to two groups: Group I, for those who had already undergone surgical treatment for decompression and posterior approach instrumented arthrodesis, (Figure 1) and Group 2, those awaiting surgery. All patients recruited were submitted transversally to a clinical evaluation by means of established questionnaires such as the Short Form 36 (SF36), ${ }^{9}$ the Oswestry Disability Index (ODI), ${ }^{10}$ and the visual analog scale for pain (VAS). The SF36, a generic tool for evaluating the quality of life, is a multidimensional questionnaire that is easy to administer and understand, consisting of 36 items, grouped into 8 scales or components: functional capacity, physical aspects, pain, general state of health, vitality, social aspects, emotional aspects, and mental health. The ODI is used for functional assessment of the lumbar spine, incorporating measurements of pain and physical activity. The scale consists of 10 questions with six alternatives. The first question evaluates pain intensity and the other nine, the effect of pain on day-to-day activities. Patients in Group 1 were asked whether they would have preferred not to have undergone surgery.

The statistical analysis compared the two groups using the Student's t-test. A value of $p<0.05$ was considered indicative of statistical significance. Both unidirectional and bidirectional variance analyses were performed, the former to show whether the result was better or worse, and the latter to show whether the result was different from the control group, regardless of whether it was better or worse.

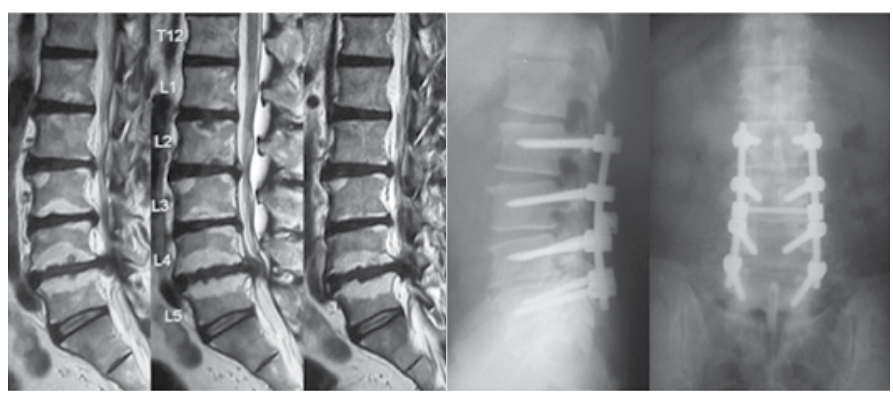

Figure 1. Clinical case - patient who underwent surgical treatment.

\section{RESULTS}

The allocation of the patients into groups identified 12 patients who underwent surgical treatment (Group 1) and 18 patients awaiting the same procedure (Group 2). The average age of Group 1 was 59 years (43-70) and in Group 2 it was 55 years of age (37-82) $(p=0.3)$. In terms of sex, Group 1 had $59 \%$ women and $41 \%$ men, as opposed to $79 \%$ women and $22 \%$ men in Group 2.

The "functional capacity", "pain", and "limitation from physical aspects" components of the SF36 were analyzed together with the ODI, and also the visual analog scale (VAS) for pain. The group that underwent surgery had an average ODI of 38.67, compared to 59.72 for the group awaiting surgery, with a statistically significant difference. The analog pain scale had a score of 5.33 for lower back pain and 3.83 for pain radiating to the lower limbs in Group 1, as compared to 6.78 and 7.22, respectively, in Group 2.

As regards the results of the SF36, functional capacity, limitation due to physical aspects and pain had average scores of 36.25, 19.58 , and 21.67 in the patients who underwent surgery, as compared to $35.94,27.50$, and 32.61 , respectively, in those who had not yet undergone surgery. The results are shown schematically in Figure 2 and Table 1.

Figure 2 needs to be interpreted bearing in mind that, contrary to the VAS and Oswestry systems, the higher the result in the values of the SF36, the fewer symptoms the patient will present. Table 1 below shows the values obtained, and their statistical analysis, both for the expected unidirectional result and for the undetermined multidirectional value (better or worse), in accordance with the Student's t-test method of application.

Through an analysis of the results between the groups, we can see that none of the parameters of the SF36 quality of life questionnaire had a significant difference. Moreover, a worse result was observed for pain and limitations due to physical aspects in the operated group.

When the patients in Group 1 (those who underwent surgical treatment) were asked if they wished they had not undergone surgery, 25\% (4/12) responded yes, and 75\% (8/12) said no, that they had improved following surgery. 




Figure 2. Graphic analysis of results.

Table 1. Result of the questionnaire and statistical calculation.

\begin{tabular}{c|c|c|c|c|c|c|c}
\hline & & & & \multicolumn{3}{|c}{ SF36 } \\
\hline Average & Age & Oswestry & $\begin{array}{c}\text { Lumbar } \\
\text { VAS }\end{array}$ & $\begin{array}{c}\text { Leg } \\
\text { VAS }\end{array}$ & $\begin{array}{c}\text { Func } \\
\text { Cap }\end{array}$ & $\begin{array}{c}\text { Limita- } \\
\text { tion }\end{array}$ & Pain \\
\hline Operated & 59.08 & 38.67 & 5.33 & 3.83 & 36.25 & 19.58 & 21.67 \\
\hline Awaiting & 55.11 & 59.72 & 6.78 & 7.22 & 35.94 & 27.50 & 32.61 \\
\hline $\begin{array}{c}\text { Student } t \text { variation } \\
\text { bidirectional }\end{array}$ & $\mathbf{0 . 3 0 5 0}$ & $\mathbf{0 . 0 0 4 6}$ & $\mathbf{0 . 2 4 9 1}$ & $\mathbf{0 . 0 1 2 5}$ & $\mathbf{0 . 9 7 3 8}$ & $\mathbf{0 . 5 5 3 3}$ & $\mathbf{0 . 3 7 6 3}$ \\
\hline $\begin{array}{c}\text { Student } t \text { variation } \\
\text { unidirectional }\end{array}$ & & $\mathbf{0 . 0 0 2 3}$ & $\mathbf{0 . 1 2 4 5}$ & $\mathbf{0 . 0 0 6 2}$ & $\mathbf{0 . 4 8 6 9}$ & $\mathbf{0 . 2 7 6 6}$ & $\mathbf{0 . 1 8 8 1}$ \\
\hline
\end{tabular}

\section{DISCUSSION}

Degenerative lumbar stenosis is a disease that is increasingly identified in the population, due both to the aging of the population and easier access to medical assistance and imaging exams that can confirm the condition. ${ }^{7}$ Despite this real increase in incidence, the real benefit of surgical decompression treatment for this population is not clear.
This study showed that patients with lumbar stenosis without spondylolisthesis, with diagnoses confirmed by magnetic resonance, benefit from surgery, with a reduction in pain reported in the lower limbs (VAS Leg with $p<0.05$ ) and improved function (Oswestry with $p<0.05)$; however, it did not show any change in quality of life according to the SF36 scale ( $p>0.05)$.

Similarly to the findings of this study, Atlas et al., ${ }^{7}$ in an analysis of patients who either underwent surgery or were treated clinically, concluded that after 8-10 years of follow-up, both groups presented similar levels of lower back pain and satisfaction with their respective treatments, but the operated group had better function and reported less pain in the lower limbs.

Weinstein et al. ${ }^{3}$ conducted a multicenter prospective study in the SPORT (Spinal Patient Outcomes Research Trial) group and concluded that in the group "according to the treatment implemented", the operated patients showed significant improvement in pain, function, and satisfaction when compared to the non-operated patients.

Although not all the questions showed significant improvement, the patients who underwent surgery did not regret having undergone the treatment. One criticism of this study is that because it was retrospective, it lacked a comparison of the questionnaire responses from the same patient before and after the procedure. Thus, despite the improvement obtained, in some cases, patients may not consider their own level of satisfaction with the treatment to be very high (according to the scores), but recall that they were worse prior to the procedure, and so do not regret having undergone the procedure.

\section{CONCLUSION}

In patients with lumbar stenosis of the vertebral canal, there was no change in the quality of life of patients operated on, when compared with those awaiting the procedure; however, there was a significant improvement in the levels of incapacity and pain in those who underwent surgical treatment. Most of the operated patients did not regret having undergone procedure.

\section{ACKNOWLEDGEMENTS}

We thank Rafael Carboni de Souza, Rodrigo Góes Medéa de Mendonça and José Alfredo Corredor Santos.

All authors declare no potential conflict of interest concerning this article.

\section{REFERENCES}

1. Dunlop RB, Adams MA, Hutton WC. Disc space narrowing and the lumbar facet joints. $J$ Bone Joint Surg Br. 1984;66(5):706-10.

2. Amundsen T, Weber H, Nordal HJ, Magnaes B, Abdelnoor M, Lilleâs F. Lumbar spinal stenosis: conservative or surgical management?: A prospective 10-year study. Spine (Phila Pa 1976). 2000 :25(11):1424-35.

3. Weinstein JN, Tosteson TD, Lurie JD, Tosteson ANA, Blond E, Hanscom B, et al. Surgical versus Nonsurgical Therapy for Lumbar Spinal Stenosis. N Engl J Med. 2008:358(8):794-810.

4. Zylbersztejn S, Spinelli LF, Rodrigues NR, Werlang PM, KisakiY, Rios ARM, et al. Estenose Degenerativa da Coluna Lombar. Rev Bras Ortop. 2012:47(3):286-91.

5. Grivas TB, Vasiliadis E, Papadakis SA, Mouzakis V, Segos D. Quality of life after surgical decompression of lumbar spinal stenosis with and without instrumentation. Stud Health Technol Inform. 2006;123:456-60.

6. Johnsson KE, Udén A, Rosén I. The effect of decompression on the natural course of spinal stenosis. A comparison of surgically treated and untreated patients. Spine (Phila
Pa 1976). 1991;16(6):615-9

7. Atlas SJ, Keller RB, Wu YA, Deyo RA, Singer DE. Long-term outcomes of surgical and nonsurgical management of lumbar spinal stenosis: 8 to 10 year results from the maine lumbar spine study. Spine (Phila Pa 1976). 2005;30(8):936-43.

8. Radcliff K, Kepler C, Hilibrand A, Rihn J, Zhao W, Lurie J, et al. Epidural steroid injections are associated with less improvement in patients with lumbar spinal stenosis: a subgroup analysis of the Spine Patient Outcomes Research Trial. Spine (Phila Pa 1976). 2013:38(4):279-91.

9. Ciconelli RM, Ferraz MB, Santos W, Meinãol, Quaresma MR. Tradução para a língua portuguesa e validaçãoo do questionário genérico de avaliaçãoo de qualidade de vida SF36 (Brasil SF-36). Rev Bras Reumato. 1999;39(3):143-50.

10. Vigatto R, Alexandre NM, Correa Filho HR. Development of a Brazilian Portuguese version of the Oswestry Disability Index: cross-cultural adaptation, reliability, and validity. Spine (Phila Pa 1976). 2007;32(4):481-6. 